\title{
EDITORIAL
}

\section{MIGRATION AND DISPLACEMENT: HUMANITY WITH ITS BACK TO THE WALL}

\section{Vincent Bernard, Editor-in-Chief}

Crowds of people on the move with their bundles of possessions, young men frantically scaling fences, boatloads of women and children pummelled by the waves, bodies washed up the beach, camps with endless rows of tents and chaotic shanty towns stretching as far as the eye can see, transit centres where hopes fade, humiliated workers forced to do jobs nobody else wants, mothers waiting a lifetime in vain for news of daughters or sons who left to seek their fortune elsewhere. These are some of the images that might come to mind when picturing the plight of uprooted people around the world.

Several months ago, the attention of Europe and the world was focused on the crisis that began to unfold in 2015 as millions of Africans, Afghans, Syrians and Iraqis attempted to cross the Mediterranean, fleeing conflict and poverty. The crisis continues but the media spotlight has shifted to the ordeal suffered by people displaced from the cities of Iraq and Syria and to US migration policy, in particular the plans to build a wall on the border with Mexico. As we write, the headlines are dominated by the situation in Myanmar and its neighbouring countries as an entire people flees. On the other hand, there are other places in Africa, Central and South America, where such crises do not make headlines. The never-ending string of such dramas and the masses of people uprooted from their homes on a scale not witnessed since the Second World War have prompted the Review to devote another issue to the topic of displacement and migration. ${ }^{1}$

The brunt of the "migration crises" is borne not by countries in Europe and North America, as many journalists and politicians are wont to suggest, but by host countries in the South and, most importantly, by the families, single adults and children lost in the multitude who have set out on a journey into the unknown, leaving everything behind. These crises are just the tip of the iceberg, the predictable consequences of an endless succession of conflicts and disasters and persistent underdevelopment.

While migrants arriving on the doorsteps of destination countries are undoubtedly the most visible manifestation, there are millions more people displaced within their own countries facing the same difficulties. Why do these people leave their homes, exposing themselves to so many risks? What can be done to help them resume normal life?

1 Previous issues of the Review have been devoted to refugees in armed conflict ("50th Anniversary of the 1951 Refugee Convention: The Protection of Refugees in Armed Conflict", Vol. 83, No. 843, 2001) and displacement ("Displacement", Vol. 91, No. 875, 2009). 


\section{A brief history of hospitality}

History is studded with stories of forced displacement featuring persecuted religious minorities, civilians fleeing bombed cities, expelled political opponents and entire communities driven from their lands by war or famine, and each time they put the humanity of those they encounter along the way to the test.

Exoduses of the past are remembered through tales of the suffering experienced by those exiled, but also of the exceptional resources they summoned from within to overcome the difficulties encountered and the degree of generosity or hostility with which they were received by their hosts. We are required by the most basic sense of humanity to help those fleeing for their lives as best we can, welcoming them to stay for some time or for good. In legal terms it is a duty to rescue and not doing so constitutes a failure to render assistance to a person in danger, which constitutes a crime in many civil law jurisdictions. History is rife with examples of peoples that have opened their arms to foreigners and seen their cultures greatly enriched as a result. There is much to be learned from studying the history of crises and hospitality. With this in mind, the Review and the International Committee of the Red Cross (ICRC) mission to the United Kingdom, together with the Arts and Humanities Research Council, jointly organized the conference "Forced to Flee" in London, with a view to looking at the history of the response to population movements and drawing lessons for the present. ${ }^{2}$ This history shows how successive crises have progressively brought about innovations in the international response in terms of transnational governance and humanitarian standards and best practices based on experience.

The idea that a person in danger should not be turned away but should be offered hospitality is very ancient. The right to asylum was recognized by the Greeks (asylon - inviolability) and the Romans (asylum) in certain sanctuaries, and later by Christians in churches. Judaism, Christianity and Islam all feature flight from persecution in their founding stories: the exodus of the Hebrews, led by Moses, to the promised land; the flight of the Holy Family to Egypt to escape persecution by King Herod; and the hegira, the flight of the Prophet and his followers from Mecca to Medina, marking the beginning of the Islamic era.

This principle was put forward as an international rule for the first time by Grotius (1583-1645), a Dutch jurist who was himself in exile in Paris at a time when large migration movements were under way, mainly as a result of religious persecution (Jews and Muslims in Spain, Catholics in England, Protestants in France, etc.). In his legal masterpiece De jure belli ac pacis (On the Law of War and Peace), Grotius wrote:

2 See the report in this issue of the Review, also available at: www.icrc.org/en/international-review/article/ forced-flee-multi-disciplinary-conference-internal-displacement (all internet references were accessed in February 2018). 
Furthermore a permanent residence ought not to be denied to foreigners who, expelled from their homes, are seeking a refuge, provided that they submit themselves to the established government and observe any regulations which are necessary in order to avoid strifes. ${ }^{3}$

This principle today forms the basis for the international rules that protect refugees, a term that comes from the Latin verb fugere, meaning "to flee". The 1793 constitution of revolutionary France introduced the idea of the country as a land of asylum for political opponents. Article 120 states that the French people will "give asylum to foreigners banished from their homeland for the cause of freedom and deny asylum to tyrants". ${ }^{4}$

The French Revolution ushered in a century of revolutionary and nationalist upheaval, with its famous emigrés and expelled citizens (such as Victor Hugo, Karl Marx and Chopin) but also its great social movements and large-scale migration. The First World War marked the start of the age of mass population movements that we continue to witness today. The ideological, social and territorial shockwaves it sent around the world were to trigger a series of major exoduses, including the Armenians and Greeks from Anatolia, the White Russians, and the Turks from Greece. It was in response to these crises that the foundations of the current international asylum system were laid in the 1920s. The famous Nansen passport, named after the first High Commissioner for Refugees and issued to Russians and Armenians who had been left stateless, was the hallmark of the response to these events. It was also at this time that efforts aimed at professionalizing humanitarian action really got under way in order to address the scale of the challenges posed. In an attempt to break through the indifference of populations still picking up the pieces after the Great War, humanitarian organizations resorted to the use of "propaganda". The ICRC, for example, took advantage of the cinema boom to promote its action to assist refugees and prisoners of war awaiting repatriation. ${ }^{5}$

The Second World War was to trigger unprecedented population movements within and between countries in Europe and elsewhere: the "exodus" of French and Belgian nationals in 1940, the displacement of millions of Germans following the fall of Nazism, and the odyssey of Shoah survivors, symbolized by the voyage made by the passengers of the Exodus in 1947.

The adoption of the four Geneva Conventions in 1949 and their Additional Protocols in 1977 reinforced the protection of civilians in armed conflicts. Under international humanitarian law (IHL), the forced displacement of the population

3 Hugo Grotius, De jure belli ac pacis, Book II, Ch. 2, XVI.

4 See, Art. 120 of the "Declaration des droits de l'homme et du citoyen", French Constitution of 24 June 1793, available at: www.conseil-constitutionnel.fr/conseil-constitutionnel/francais/la-constitution/lesconstitutions-de-la-france/constitution-du-24-juin-1793.5084.html.

5 Enrico Natale, "Quand l'humanitaire commençait à faire son cinema", International Review of the Red Cross, Vol. 86, No. 854, June 2004; ICRC, "Humanitarian Action and Cinema: ICRC Films in the 1920s", news release, 18 April 2005, available at: www.icrc.org/eng/resources/documents/news-release/ 2009-and-earlier/6bkkyc.htm. 
is prohibited and civilians may only be evacuated to protect their security or if imperative military reasons demand it. ${ }^{6}$

It was also at the end of the Second World War that the current system of protection for refugees was put in place with the adoption of the 1951 Refugee Convention. Its definition of the term "refugee" remains valid today. According to this definition, a refugee is any person who,

owing to well-founded fear of being persecuted for reasons of race, religion, nationality, membership of a particular social group or political opinion, is outside the country of his nationality and is unable or, owing to such fear, is unwilling to avail himself of the protection of that country; or who, not having a nationality and being outside the country of his former habitual residence as a result of such events, is unable or, owing to such fear, is unwilling to return to it. $^{7}$

Although the Convention has often been criticized for its limitations in respect of mass population movements, the broad criteria it sets out have allowed the interpretation of refugee status to evolve with successive crises.

In recent decades, the plight of people displaced within their own country has become a major concern, heightened by the fact that today's conflicts tend to be protracted, preventing displaced populations from returning to their homes. The world only began to realize the extent of the problem of internal displacement when Guiding Principles were adopted in $1998^{8}$ and efforts were undertaken to start documenting the problem. ${ }^{9}$ The fact that internally displaced persons (IDPs) stay in their country of origin means that they remain, in theory, under the protection of their own government. They are not therefore granted a specific legal status under international law, as refugees are. This is why the adoption of the first binding regional instrument concerned with assistance and protection for displaced people in Africa - the Kampala Convention - has been hailed as a major achievement. ${ }^{10}$

6 In this regard, see Geneva Convention IV, Arts 49, 147; Additional Protocol I, Art. 85 (4) (a); Additional Protocol II, Art. 17; customary IHL Rules 129 (act of displacement) and 130 (transfer of own civilian population into occupied territory); and other customary IHL rules specifically dealing with displaced persons under IHL - Rules 131 (treatment of displaced persons), 132 (return of displaced persons) and 133 (property rights of displaced persons), available at: ihl-databases.icrc.org/customary-ihl/eng/docs/ v1_rul.

7 Convention relating to the Status of Refugees, 189 UNTS 150, 28 July 1951 (entered into force 22 April 1954), Art. 1.

8 UN Office for the Coordination of Humanitarian Affairs, Guiding Principles on Internal Displacement, UN Doc. E/CN.4/1998/53/Add.2, 11 February 1998.

9 The role of collecting and analyzing data on all situations of internal displacement was entrusted to the Internal Displacement Monitoring Centre (IDMC) in 1998. For more information, see the IMDC website, available at: www.internal-displacement.org/about-us/.

10 African Union Convention for the Protection and Assistance of Internally Displaced Persons in Africa (Kampala Convention), 22 October 2009 (entered into force 6 December 2012). The ICRC has carried out a stocktaking exercise on the implementation of the Kampala Convention in order to determine how States can best meet their obligations to internally displaced persons. See the report in this issue of the Review. 
Large-scale migration also occurs for economic reasons, with people leaving their homes to escape poverty and make a better life for themselves. While some do, in fact, make a conscious decision to leave, we have to ask ourselves if this can really be called a choice when dire conditions mean that they have no job prospects or access to decent education or health care.

Every era has its "El Dorados". The national identity of the United States, Australia and many Latin American countries is built around the melting-pot myth. For the Italian, Irish and Polish migrants who disembarked in New York in the 1900s, the "American dream" meant the opportunity to settle and make their fortune, regardless of their origin. The pedestal of the Statue of Liberty bears the inscription of a poem by Emma Lazarus, entitled "The New Colossus", which includes the following lines:

Give me your tired, your poor,

Your huddled masses yearning to breathe free,

The wretched refuse of your teeming shore.

Send these, the homeless, tempest-tost to me,

I lift my lamp beside the golden door!

Reality and myth do, of course, always diverge to some extent. Even in the shadow of the Statue of Liberty, walls were erected, the "paper walls" that historian D. S. Wyman ${ }^{11}$ describes, referring to the snarls of red tape that immigrants had to unravel.

Europe had long been a land of emigration, particularly to the United States, but after the Second World War it became a place of immigration, encouraging workers to come, especially from former colonies, to take part in the reconstruction of the region and contribute to its growth. Today, the prosperity of Europe and North America is a powerful pull factor for people in the countries of the South, although those who come seeking a better life are often disappointed.

Being a host is not always easy, especially when communities face a massive influx of people or lack the means to meet even their own needs. Should we open the "golden door" wide or build a wall? Should we coop foreigners up in camps to wait for a hypothetical return, like the millions of Palestinians in camps in Gaza, the West Bank, Lebanon and Jordan since the wars in 1948 and 1967 or the Somalians in the Dadaab camp in Kenya?

With the passing of time, the notion of asylum has become ambivalent, and it can now have the diametrically opposed meanings of hospitality and of being set apart. The term "asylum", previously used to refer to institutions for the mentally ill or the elderly, has taken on ambiguous connotations as both a place of welcome and care and a place of confinement. In this age of mass movements, awkward compromises have been made between closure and openness, which some refer to

11 D. S. Wyman, Paper Walls: America and the Refugee Crisis, 1938-1941, University of Massachusetts Press, Amherst, MA, 1968. 
as "encampment" policy. ${ }^{12}$ Camps have become a modern purgatory, between the hell of rootlessness and the heaven of integration. Camps are usually set up in haste in response to waves of displacement, but keeping them open on a longterm basis raises a series of human, social and security problems without providing the people living in them with opportunities for the future. In the words of Michel Agier, author of Les migrants et nous (Migrants and Us), when large-scale camps were created in response to emergencies in the 1990s,

a "humanitarian government of undesirables" was born, with the separation of a vulnerable remnant population, treated as a world apart from our own and contemplated from afar with compassion but also with fear and/or hostility. Camps have taken on a completely different meaning in this new context. They are both inside and outside. They form part of global "governance" but as if they were the place for second-class citizens to live. ${ }^{13}$

Today, "managing" migration flows has an ambiguous connotation; while many human lives may have been saved thanks to the European Union's Frontex operations at sea or to the funding provided for the reception of migrants in a number of countries (for example, the agreement between the European Union and Turkey ${ }^{14}$ ), these initiatives have also come under fire. Held up as measures designed to achieve "humanitarian" aims, they can also give States a way out of their responsibilities in terms of non-refoulement ${ }^{15}$, by creating a buffer around their borders and outsourcing migrant reception to third countries. This could end up putting people seeking to emigrate in dramatic and/or hopeless situations in camps or detention centres. The "containment" of migrants makes migration an even more daunting prospect. According to Peter Maurer, "there needs to be a collaborative approach among States aimed at the well-being of individuals, and not to deter migration and punish those who decide to leave their communities. Security concerns must be balanced against humanitarian considerations." 16

12 See Guglielmo Verdirame and Barbara Harrell-Bond, Rights in Exile: Janus-Faced Humanitarianism, Berghahn Books, New York, 2005.

13 Interview with Michel Agier, "Le temps de l'encampement", L'Histoire, No. 73, October-December 2016, p. 87. Translation by the Review.

14 For more information on the deal, see European Council, "EU-Turkey Statement", press release, 18 March 2016, available at: www.consilium.europa.eu/en/press/press-releases/2016/03/18/eu-turkeystatement/ and European Commission, "EU-Turkey Statement: Questions and Answers", 19 March 2016, available at: europa.eu/rapid/press-release_MEMO-16-963_en.htm.

15 Non-refoulement is considered to be a cardinal principle of international refugee law and the cornerstone for international protection (see, among others, UNHCR, Advisory Opinion on the Extraterritorial Application of Non-Refoulement obligations under the 1951 Convention relating to the Status of Refugees and its 1967 Protocol, Geneva, 26 January 2007, p. 2.). This principle can be found in some variations in different bodies of international law. (Cordula Droege, "Transfers of Detainees: Legal Framework, non-refoulement and Contemporary Challenges", International Review of the Red Cross, Vol. 90, No 871, 2008). See, also, "Note on Migration and the principle of non-refoulement" in this issue of the Review.

16 Peter Maurer, "The Critical Challenges of Migration and Displacement", statement, 18 October 2017, available at: www.icrc.org/en/document/speech-migration-and-internal-displacement-nationaland-global-challenges. 
When foreigners are able to settle in a new community, the question of how hosts and newcomers will live together arises. Will the hosts integrate the newcomers into their community, respecting their linguistic, cultural and religious differences, or conversely, try to assimilate them into the melting pot?

A willingness to receive migrants can therefore be seen as naive or even subversive and dangerous in a climate of anxiety about identity and a deepening isolationism. Times change, and successive economic crises, fears about terrorism and xenophobic political movements have left their mark. Wide swathes of public opinion and numerous governments do not see immigration in terms of a duty of solidarity or of economic benefits (as an injection of labour and skills into an ageing population) but as a threat to national identity and security. By the same token, people fleeing conflicts and persecution can be perceived not as victims, but as dangerous intruders or potential terrorists.

Although enshrined in the legal, moral and religious norms, hospitality is regarded as just another "political opinion". It therefore takes a rare act of political courage to say, as Angela Merkel did on 31 August 2015, "Wir shaffen das" ("We can do it"). ${ }^{17}$

\section{"What's in a name?" Different names but the same ordeal}

People leave their homes for a wide variety of often overlapping reasons, and the status granted to them under domestic or international law is a factor of great importance in determining the protection they receive and their future. Nonetheless, whether they are fleeing from conflicts or disasters, or are simply seeking a better future for their family, whether they cross borders or are displaced within their own country, these people often face the same hardships and encounter the same pitfalls along the way. ICRC President Peter Maurer described the difficulties they experience in the following terms:

Once on their journey, migrants and IDPs face multiple risks and high degrees of vulnerability. When they reach their destination they often face difficulties in accessing health care, housing, education or employment. They may become easy targets for abuse, extortion and exploitation due to a lack of a protective family network, a lack of information or missing documents. Many suffer accidents or illness and cannot benefit from medical care. Some lose contact with their families. Thousands die or disappear along the way every year. Many are held in prolonged detention for having entered or stayed irregularly in a foreign country, in disregard of the fact that detention should always be an exceptional measure of last resort and limited in time. ${ }^{18}$

17 Phoenix, "Flüchtlingspolitik: 'Wir schaffen das'-Statement von Angela Merkel am 31.08.2018”, 31 August 2016, available at: www.youtube.com/watch?v=kDQki0MMFh4.

18 P. Maurer, above note 16. 
The danger of establishing different types of treatment for different categories of people is that they risk being labelled, classified and treated with different degrees of humanity.

Given the unprecedented number of uprooted people, but also the politicization of the discourse on migration, the International Red Cross and Red Crescent Movement (the Movement) has adopted a broad description of the people it seeks to assist and protect, taking into account their needs rather than their status. The components of the Movement and other humanitarian actors uphold the same humanitarian principles, in particular the principle of impartiality, in their humanitarian response. The title of this issue ${ }^{19}$ is therefore deliberately broad so that contributors can provide insights across all dimensions of this phenomenon.

The Review does not intend, with this choice of title, to disregard or make light of the different types of legal status that people can seek, such as refugee status; it is simply a reflection of the approach that the components of the Movement wish to adopt in their humanitarian response. As the British Red Cross says on its website, "whenever we see people who need help, we don't demand to see their passports. We just give them help and dignity - something we would all expect after a brutal journey into the unknown."20

In accordance with this vulnerability-based approach, ${ }^{21}$ the components of the Movement are there on the front line, carrying out a wide range of activities to assist IDPs and migrants. The Review has asked several National Societies with experience in this field, namely the Australian, British and Honduran Red Cross Societies, to contribute to this issue, highlighting their work in addressing the needs of migrants and displaced persons.

As noted in observations made by Movement components working on the ground, some of the most serious humanitarian problems related to the phenomenon of migration and displacement are missing migrants, unaccompanied minors (an especially vulnerable group of migrants), immigration detention, the issue of data protection and urban displacement.

The matter of the fate of missing migrants is a particularly harrowing one. Thousands of people have gone missing at $\operatorname{sea}^{22}$ and along migration routes in recent years. Thousands of bodies have been buried without any attempt to

19 In this issue, the term "internally displaced persons" refers to people who are forced to leave their homes but stay in their own country, and the term "migrants" to people who have left their homes crossing one or more international borders (including refugees).

20 Craig Burnett, "Why Do We Help Refugees and Migrants?", British Red Cross Blog, 9 September 2015, available at: blogs.redcross.org.uk/emergencies/2015/09/why-do-we-help-refugees-and-migrants/.

21 For more on the meaning of the vulnerability approach, see, for instance, International Federation of Red Cross and Red Crescent Societies, "Policy on Migration", November 2009, Introduction, available at: media.ifrc.org/ifrc/what-we-do/migration/policy-strategy/; ICRC, "ICRC Policy Paper on Immigration Detention", April 2016, in this issue of the Review.

22 For considerations on the search and collect of the wounded, sick, shipwrecked and dead at sea in times of armed conflicts and an introduction to the updated Commentary to the Second Geneva Convention, see Bruno Demeyere, Jean-Marie Henckaerts, Heleen Hiemstra and Ellen Nohle, "The Updated ICRC Commentary on the Second Geneva Convention: Demystifying the Law of Armed Conflict at Sea", International Review of the Red Cross, Vol. 98, No. 902. 
identify them, and thousands of children have been separated from their parents. The unbearable uncertainty suffered by families who do not know what has happened to their loved ones is one of the most tragic and least visible consequences of mass population movements. This issue of the Review opens with testimonies of families of missing migrants in Zimbabwe. These testimonies serve to show the everyday struggle, difficulties and ambiguity of not knowing the whereabouts or the fate of loved ones that those who stay behind are faced with. The ICRC recently published recommendations on missing migrants, ${ }^{23}$ drawing on its extensive experience in restoring family links in conflicts. The policy paper emphasizes the need to standardize the way in which information about missing persons and human remains are collected and processed, bringing procedures into line with international standards. These recommendations also cover cooperation among the actors involved - including families - at the national and international level.

Another pressing problem is that of unaccompanied minors. The British Red Cross contribution to this issue addresses the problem in Calais, a specific case that came into the spotlight of media attention in 2015. The need for an urgent, efficient and adequate response demanded a lot of coordination and collaboration, always keeping in mind the specificities of the vulnerabilities of the migrants in question and tailoring a response to them.

The challenges with which humanitarian organizations are faced when it comes to data protection are ever-growing. It comes as no surprise that the humanitarian world needs to adapt fast, keeping in mind the outer limits of experimentation and the ways it might be detrimental to the "do no harm" principle. For this reason, this issue of the Review explores this important topic, especially keeping in mind the problematic issues of migrants and displaced persons, data protection and humanitarian action.

Migration management takes on different forms, one of them being immigration detention. In order to stop irregular migration, meaning entry into or stay or residence in a country of which the individual is question is not a national without proper documentation, some States resort to administrative or criminal detention. The problems and consequences of choosing detention as a tool rather than alternatives to detention ${ }^{24}$ vary, but as the phenomenon is gaining pace and detention conditions can and sometimes do cause harsh physical and mental health problems, the ICRC has outlined key points for States to bear in mind in this regard. ${ }^{25}$

Recent developments have seen numerous IDPs and migrants seeking refuge in cities. The Review has explored the topic of urbanization in its recent

23 ICRC, Policy Paper on Missing Migrants: The ICRC's Recommendations to Policy-Makers, Geneva, August 2017, available at: www.icrc.org/en/document/missing-migrants-icrc-recommendations-policy-makers.

24 For more information, see International Detention Coalition, "Alternatives to Detention", available at: idcoalition.org/alternatives-to-detention/.

25 The ICRC, driven by the protection and assistance needs of migrants held in detention, published a policy paper on immigration detention, outlining main considerations for States to bear in mind. See ICRC, "ICRC Policy Paper on Immigration Detention", in this issue of the Review. 
issue on "War in Cities". ${ }^{26}$ As was noted therein, the world is undeniably urbanizing and so are migration and displacement. The issue of urban internal displacement (coupled with the need for an adequately tailored humanitarian response), the search for appropriate and timely solutions and the specificity of the effects of urban IDPs on host communities are explored in this issue of the Review.

Useful insights can be gained from looking at the reasons why women and men leave their homes in the specific context of armed conflict. It is well-known that armed conflict is a major cause of displacement. Even in an armed conflict in which IHL is fully respected, people will likely be displaced. War, by its very nature, systematically causes population movements as people flee the violence or find that they cannot live in the conflict-ravaged area owing to the lack of material resources. But is displacement an immutable phenomenon over which we have no control, or can the scale and patterns of such movements be influenced by factors such as respect for the rules of IHL? Compliance or noncompliance with this body of law seems to have a very real and significant impact on the causes of displacement in times of war. The ICRC is currently conducting a study on the links between IHL and displacement. The findings will be published in 2018 and should provide a better understanding of the way in which compliance with or violation of the law can directly influence the scale and duration of displacement.

\section{Humanity with its back to the wall}

While the Review provides a humanitarian perspective on migration and displacement, the medium- and long-term international response to current developments must go beyond that. The idea of global governance is gaining ground in today's increasingly interdependent and globalized world, and migration and displacement are clearly concerns for this governance in which States have the primary responsibility. Humanitarian actors are nevertheless also called on to play an important role in this respect, highlighting the human consequences, distinguishing real solutions from quick fixes and political posturing, and helping to foster empathy and win over public opinion.

On 19 September 2016, 193 States adopted the New York Declaration for Refugees and Migrants, in which the United Nations (UN) General Assembly expressed its intention to develop a "global compact for safe, orderly and regular migration" and a "global compact on refugees". The Global Compact for Migration will be the first intergovernmentally negotiated agreement prepared under the auspices of the UN to cover all dimensions of international migration in a holistic and comprehensive manner. The process to develop the Compact started in April 2017. The General Assembly will hold an intergovernmental 
conference on international migration in 2018, with a view to adopting the global compact. ${ }^{27}$ The ICRC has published a comment ${ }^{28}$ in which it voices its concerns about the political unease that the recent crises have caused and puts forward its recommendations on clear commitments for the international community.

The New York Declaration also gave the UN High Commissioner for Refugees the task of building on the Comprehensive Refugee Response Framework to develop a Global Compact on Refugees, and he will propose the text in his 2018 report to the UN General Assembly. This issue of the Review features an interview with High Commissioner Filippo Grandi, who talks about the current crises, his organization's priorities and the preparation of the Global Compact on Refugees.

Human mobility is a natural dimension of humanity, and everything suggests that it can only continue to increase in our globalized world. The issue of migration is at the heart of the agenda today, doubtless due to the massive influx of people knocking on the doors of prosperous nations. This influx is a result of protracted conflicts, crimes against civilians and the march of globalization.

While it is true that mass population movements have reached harrowing proportions, the history of hospitality shows us that major crises in the past have often led to a surge in solidarity and the progressive extension of the international system of protection. Effective solutions are urgently needed for people on the move, in camps, at the border of rich nations and in countries at war, because time lost will cost more human lives.

The question now is, will the scale of today's crises trigger new progress in stepping up the international response? Or on the contrary, will we see more walls being erected to repel people perceived as the "invaders", the "terrorists" and the dangerous "unknown"? As we can discern from the cover photo of this issue, the labels we give are just a reflection, an image in our minds, of the lives of real women, men and children. They all have the right to be treated with humanity.

27 At the time of writing, the Zero Draft of the Global Compact for Safe, Orderly and Regular Migration had been published, available at: refugeesmigrants.un.org/intergovernmental-negotiations. The draft was prepared by the co-facilitators from Mexico and Switzerland, and it represents the official commencement of the intergovernmental negotiation phase.

28 ICRC, "ICRC Comments on the Global Compact for Safe, Orderly and Regular Migration", 6 July 2017, available at: www.icrc.org/en/document/icrc-comment-global-compact-safe-orderly-and-regularmigration. 